HORIZON 7 (1) 2018 : I. Research : G. J. Giubilato : 203-222

ФЕНОМЕНОЛОГИЧЕСКИЕ ИССЛЕДОВАНИЯ • STUDIES IN PHENOMENOLOGY • STUDIEN ZUR PHÄNOMENOLOGIE • ÉTUDES PHÉNOMÉNOLOGIQUES

https://doi.org/10.21638/2226-5260-2018-7-1-203-222

\title{
BEYOND THE GENESIS, TOWARD THE ABSOLUTE. EUGEN FINK'S ARCHITECTONIC FOUNDATION OF A CONSTRUCTIVE PHENOMENOLOGY BETWEEN A META-CRITIC OF TRANSCENDENTAL EXPERIENCE AND HIS OWN PROJECT OF A DIALECTICAL MEONTIC
}

\section{GIOVANNI JAN GIUBILATO}

PhD in Philosophy, Post-Doc Fellow.

Federal University of Londrina (UEL), Philosophy Department.

86057-970 Londrina, Brazil.

E-mail: giovannijangiubilato@hotmail.com

While Eugen Fink was working on the revision of Husserl's five Cartesian Meditations and preparing them for publication as a magnum opus for the German public, which - as Husserl itself claimed required a truly phenomenological counterweight to Heidegger's Being and Time, he not only sought a presentation of the vivid and most actual insights that guided the phenomenological philosophy but also stressed the urgent need to integrate their achievements in order to overcome their philosophical naiveté. This was due to the initial (and inevitable) exclusion of the deepest issues concerning phenomenology as a whole transcendental system, and particularly those regarding the total reach of evidence toward the transcendental field of experience. This sort of incompleteness had to be overcome by a solid "critic of the transcendental reason". But, whereas for Husserl the task of self-criticism was directed at an examination of the evidences acquired in the transcendental attitude, for Fink it turned out to be a totally different challenge that ended up in an innovative vertical displacement of the horizontal structure of Husserl's phenomenology. From the very beginning, Fink truly worked on a large-scale system of phenomenological philosophy and on an architectonic conception of the different stages of the pure phenomenology, in which the regressive phenomenology (transcendental aesthetic and analytic) was followed by a new progressive phenomenology (transcendental dialectic) endowed with a "constructive" method. The following article explores the emergence and relates the main topics of such constructive integration of phenomenology, whose conceptuality was only briefly foreshadowed in the famous VI Cartesian Meditation and, nonetheless, systematically developed in the large amount of Fink's private notes that constitute his own meontic philosophy.

Key words: Eugen Fink, phenomenology, architectonics, constructive phenomenology, meontic.

(C) GIOVANNI JAN GIUBILATO, 2018

HORIZON 7 (1) 2018 


\section{ЗА ПРЕДЕЛАМИ ГЕНЕЗИСА, В НАПРАВЛЕНИИ К АБСОЛЮТУ. АРХИТЕКТОНИЧЕСКОЕ ОБОСНОВАНИЕ КОНСТРУКТИВНОЙ ФЕНОМЕНОЛОГИИ ОЙГЕНОМ ФИНКОМ МЕЖДУ МЕТАКРИТИКОЙ ТРАНСЦЕНДЕНТАЛЬНОГО ОПЫТА И ЕГО СОБСТВЕННЫМ ПРОЕКТОМ ДИАЛЕКТИЧЕСКОЙ МЕОНТИКИ}

\section{ДЖОВАННИ ЯН ДЖУБИЛАТО}

Доктор философии, докторант.

Федеральный университет Лондрины (UEL), департамент философии.

86057-970 Лондрина, Бразилия.

E-mail: giovannijangiubilato@hotmail.com

Занимаясь пересмотром и подготовкой к публикации в качестве magnum opus для немецкой публики пяти Картезианских Размышлений, которые - по утверждению самого Гуссерля должны были выступить феноменологическим противовесом Бытию и времени Хайдеггера, - Финк не только искал способы представления тех ярких и наиболее актуальных актов понимания, которыми руководствовалась феноменологическая философия, но и подчеркивал насущную необходимость объединения их результатов для преодоления их философской наивности. Эта наивность была связана с первоначальным (и неизбежным) исключением принципиальных вопросов, касающихся феноменологии как трансцендентальной системы в целом, а также вопросов, связанных с полнотой очевидности в отношении трансцендентального поля опыта в частности. Такая неполнота должна быть преодолена основательной «критикой трансцендентального разума». Но если для Гуссерля задача такой самокритики была направлена на изучение очевидности, приобретенной в трансцендентальном отношении, то для Финка эта задача означала совершенно иной вызов, результатом чего стало инновационное вертикальное смещение горизонтальной структуры гуссерлевской феноменологии. С самого начала Финк работал над полномасштабной системой феноменологической философии и над архитектонической концепцией различных уровней чистой феноменологии, в которой за регрессивной феноменологией (трансцендентальной эстетикой и аналитикой) следовала новая прогрессивная феноменология (трансцендентальная диалектика), подкрепленная конструктивным методом. Данная статья исследует возникновение и указывает на основные темы такой конструктивной интеграции феноменологии, концепция которой была кратко предвосхищена в знаменитом VI Картезианском Размышлении и систематически развита в частных заметках Финка, составляющих его собственную меонтическую философию.

Ключевые слова: Финк, феноменология, архитектоника, конструктивная феноменология, меонтика.

\section{INTRODUCTION}

Eugen Fink was a regular attendant of both Husserl's and Heidegger's lectures for many years and, being deeply acquainted with both the thinking of one and the other, has been increasingly recognized as the proponent of a "third way" between 
the two great masters of philosophy in Freiburg. Working daily as Husserl's assistant and collaborator, Fink was at first assigned to the organization and the editing work of the famous "Book on the Phenomenology of Time", presenting thereby the final position of Husserlian phenomenology in relation to the problems of time-constitution and time-consciousness, once the task was to gather both Husserl's Manuscripts of Bernau and the so-called C-Manuscripts ${ }^{1}$. But Fink was also immediately involved in other projects concerning the urgency of a global systematization of the various strata of "phenomenological reason" and could therefore formulate the basis for a System of phenomenological philosophy to be developed in the context of the revision of the Cartesian Meditations, which Husserl ended up leaving entirely to his charge to finally devote himself to the greatest project of the last years of his life: the conception of the Krisis der europäischen Wissenschaften und die transzendentale Phänomenologie (Husserl, 1976a). In fact, Fink not only completed a thorough review of Husserl's five meditations but also wrote a Sixth Meditation ${ }^{2}$ regarding the so-called "transcendental theory of method", which would perform as a methodological turning point and also as a clarification of the previous five. This scenario of daily involvement with the "father of phenomenology", combined with a deep knowledge of Heidegger's thought, presents Fink as the privileged point of convergence from which we can articulate and re-engage in dialogue the monumental philosophies of Husserl and Heidegger, and, in addition, to glimpse into the third entirely original way settled by Eugen Fink himself. For the vibrant and long-standing joint philosophizing settled between Husserl and Fink (1929-1938) shows paradigmatically that "the continuation of Husserl's phenomenology for a younger generation was possible only with a profound transformation of their implicit operational presuppositions" (Van Kerckhoven, 2003, 16). However, from a continuance perspective of the phenomenological tradition through a profound transformation, the phenomenology as a whole, and not only some precise analysis of consciousness' life, had to be put into question. In this regard, the famous Fink's essay from 1939 Das Problem der Phänomenologie Husserls (Fink, 1966, 179-223) hits clearly the mark ${ }^{3}$. But unlike Heidegger, who saw in Husserl's transcen-

1 Cf. Bruzina (1993), Bruzina (1994).

2 This text was considered for a long time as a work of Husserl's authorship. On this historical matter, a note by Sebastian Luft is quite elucidative: "Among the first generation of French phenomenologists, the VI. Meditation was taken as a Husserl's writing; this was, for example, Berger's and Merleau-Ponty's view" (Luft, 2002, 5).

3 In a later text, however, Fink still intends to confront the "phenomenological motives of Husserl's and Heidegger's philosophy" with his own philosophical horizon in the lecture on Sein, Wahrheit, Welt, held in the winter semester 1955/56 at the University of Freiburg. It carries the very significant title: „Vor-Fragen zum Problem des Phänomen-Begriffs“ (Fink, 1958). 
dental phenomenology a philosophical impasse that ultimately led to a solipsistic theoreticism of consciousness and subjectivity, Fink considered the phenomenological egology in the outline of a constitutive system as well as a "certain abstraction", but "a necessary and not only possible" (Fink, 2006, 221) one. This undeniable difference in the philosophical position between Heidegger's approach and Husserl's phenomenology, which e.g. can be clearly seen already in Being and Time, could not prevent Fink from seeing in the ego, in the transcendental science of the ego and what belongs to it (i.e. in the a priori correlation system of world and subjectivity), the only possible breakthrough toward an "existential meaning of philosophy" (Fink, 2006, 221-222) Thus, for Fink, the egological approach was the one and only concrete ground for the legitimate exposition of the basic knowledge of phenomenology - despite the fact that this transcendental egology of consciousness' life was necessarily affected by a certain provisionality, by a sort of philosophical incompleteness with regard to the entirety of problems related to the concepts of inter-subjectivity and world.

Fink's phenomenological consideration could be characterized by a synoptic view of the individual truths and hidden ramifications of a philosophy - whether Heidegger's or Husserl's - which is able to pinpoint the essential connections beyond what was originally separated and divided. For a long time, Fink was consequently considered either as the appointed interpreter of Husserl's phenomenology or regarded as a philosopher obscured by Heidegger's brilliance. Both views, however, as Bruzina makes clear in his most recent and exemplary study about the intellectual cooperation between Husserl and Fink (Bruzina, 2004), are insufficient. In fact, no other previous Husserl's assistant ever had a full and active part in his work as Fink, whom was clearly acknowledged by Husserl himself as "a mind with a contribution of his own to make in the work both were involved in" (Fink, 1995, xxvii). Therefore, the many and articulated critics he made to Husserl's position, and the differences that constantly emerged during their daily encounters and large discussions, "had their identity and their force within a larger encompassing whole of common agreement" (Fink, 1995, xxxi). In other words, as Bruzina points out while discussing the nature of the co-thinking or co-philosophizing between Husserl and Fink, "the differences from Husserl that emerged in Fink's thinking were genuine problems for and within

4 Philosophy exists for Fink only because of the impetus of freedom that inhabits us, since the motivation for the reduction lies solely and exclusively in the "will to freedom" (Wille zur Freiheit). This freedom, however, is not understood in terms of the freedom as a power to do or to allow/let something (Tun- oder Lassen-Können) but rather as the liberation (Befreiung) of human existence. On Fink's early conception of phenomenology as a philosophy of freedom and on his "meontic philosophy" as a phenomenology of the absolute and as theory on freedom, see (Giubilato, 2017a; 2017b). 
transcendental phenomenology, genuine problems that developed intrinsically within it" (Fink, 1995, xxxiii). Even though problems of this order usually involves deep implications, they necessarily lead as well to a critical re-conceiving and reshaping of the phenomenological project as a whole.

\section{OVERCOMING THE PHILOSOPHICAL NAIVETÉ}

Looking back on what has been gained through his Meditations, at the end of the fifth one, Husserl explicitly writes that there is an "essential relation of phenomenology to itself" (Husserl, 1973a, 178). At this point, the assertion is not referred to the claim for self-justification and self-foundation of phenomenological philosophy, but to its operative completeness, understood by Husserl as an open system. It is a methodological necessity for phenomenology, at first, to follow a naive, straightforward-directed initial instance of evidence, while at the same time achieving essential descriptions without having to worry about the systematic whole opened up with it. Only afterward, "repeating and reflecting and carrying out reflexive descriptions" (Husserl, 1959, 477), can the critical consciousness verify to what extent unobserved conditions still may be involved in the process of those straight descriptions. The concrete work of research on the phenomena must be integrated with an infinite self-questioning; its ultimate goal is a constant review and self-examination of itself. The peculiarity of the phenomenological mode of operation is determined precisely by the fact that "no systematic design precedes concrete research, but arises in analysis itself. Yet the possibility of the whole intentional analysis blows over again the systematic design up" (Fink, 2008, 333). The resulting mobility characterizes phenomenology as an open system reflecting its dynamics in a self-questioning movement. An always new synthesis is continuously to be achieved in this ceaselessly renewable revision of the standards, which, however, can only be a provisional one. In other words, it remains valid only as long as it is not refuted by a renewed analytical insight. Otherwise, it has to be revised, even completely struck off. Accordingly, every introductory, general and systematic draft must come after the concrete analyses, which, in their turn, receive their specific relevance only in the light of the systematic context. This means that therefore the results of any single analysis, of any phenomenal inquiry, cannot be measured to their full extent unless they have been subjected to an orderly self-criticism and self-questioning. This typical retarding, inhibiting function of each individual analysis forced Husserl to ignore the problem of the full extent and reach of transcendental knowledge at the beginning of the Second Meditation. First of all, it is appropriate to justify and elaborate both the individual forms of phenomenological 
research and the overall performance of transcendental phenomenology, and only then, in hindsight, to design a possible self-criticism. As the penultimate paragraph of the Meditations concludes the first reflexive exploration of the transcendental experience, the procedure followed thereafter seemed "not yet philosophical in the full sense", because, as for a "natural scientist in his dedication to the evidence of natural experience" the "problem of a fundamental criticism of experience" (Husserl, 1973a, 69) remained totally out of question. Even if the Meditations had essentially fulfilled their purpose (as Husserl admits in the final word), they remained within a certain "philosophical naiveté" insofar as the theoretical intentional achievements - from which the exposure of the transcendental experience had arisen - had not yet been fully developed and methodically explained ${ }^{5}$. It might be the case that, from a closer perspective, some apodictic insights such as the first ones to be fixed in the subjective explication (i.e. egology) of transcendental subjectivity may later go through a transformation - as it's actually the case when phenomenological research passes over to the initially closed sphere of transcendental subjectivity.

As a matter of fact, Fink's participation in the Freiburg Phenomenology Workshop presupposes Husserl's thinking in its full development at the time and especially in the Cartesian Meditations presentation, but "it also goes further inasmuch as it expressly puts into question the methodological naiveté found throughout it" (Fink, 1995, 2). Beyond the diversified topics examined by the Meditations, the question of inter-subjectivity was the most affected by the successive attempts to determine the basis of the phenomenological system and, therefore, the most responsible for revealing the incompleteness of its first-staged topic as being nothing more than an egological disclosure of the transcendental continent. During the V. Meditation rework, no-

5 The task of such a transcendental self-criticism has in fact already been envisaged by Husserl since the lecture Grundprobleme der Phänomenologie of 1910/11. However, a detailed elaboration of the self-criticism took place for the first time in the winter semester 1922/23 lectures, Einleitung in die Philosophie. This theme was again referred to in the following year's lectures, entitled Erste Philosphie (1923/24), nevertheless only with regard to the urgent need to practice such a higher-level self-criticism. In any case, at the end of the Formal and Transcendental Logic (1929), in paragraph 107 on the "delineation of a transcendental theory of evidence as an effective intentional performance", the necessity of a transcendental self-criticism is brought back: "It was very late before I recognized [...] that this whole criticism leads back to an ultimate criticism: a criticism of those evidences that phenomenology at the first and still naive level carries on straightforwardly. But that implies: The intrinsically first criticism of cognition, the one in which all others are rooted, is transcendental self-criticism on the part of phenomenological cognition itself' (Husserl, 1969, 287-289). The task of such a phenomenology of phenomenology signified therefore the unfolding of a transcendental, apodictic critique of the sphere of evidence to which a limit is consequently set. This self-criticism corresponds essentially to the methodological elaboration of the self-referential character of phenomenology. 
toriously dedicated to a first unveiling of the "monadological inter-subjectivity", Fink became definitely aware of the fact that "if the transcendental sphere of being reaches altogether beyond the ego, then it can only occur in the form of a transcendental inter-subjectivity" (Fink, 1988, 256). And this whole new territory reaching beyond the most general structures of egological presence and constitution had yet to be explored, described and studied. It concerns therefore the exploration of the "limits" of phenomenological egology at the heart of Husserl's genetic (regressive) analysis, for the purpose of discovering the full reach (Tragweite) of transcendental subjectivity and of transcendental life. Hence, even if within "a truly Copernican revolution" the confinement of the natural attitude was broken in behalf of a progress "forward into the sphere of transcendental subjectivity", the "constitutive becoming of the world" in the transcendental life's performance of sense-foundation "had not yet been fully and properly exhibited, because all the explications of the transcendental realm had remained referred only to the 'presentness' of its reductive givenness, i.e. only to the "egological stream of life in the full concreteness of its living present" (Fink, 1995, 6). Thereby, the phenomenological proceeding had "not advanced into the properly constitutive strata of transcendental life" (Fink, 1995, 4-5). As Fink ultimately points out: "only when transcendental life has become visible to the full extent of its givenness, can one begin the move back into the depths where constitution takes place" (Fink, $1995,5)$. In order to reach these unseen depths is necessary, according to Fink, to undertake a new "examination of the external horizons of the reductive givenness" of the transcendental life, which has its "necessary motivation in the first unresolvable 'problems at the margins"' (Fink, 1995, 7) of genetic phenomenology. If some archaic processes of the original self- and world-constitution are entirely beyond the subjective and genetically matured achievements and cannot consequently be brought to any present or memorable self-givenness due precisely to the fact that it's lying beyond the limits of any phenomenological reflective and regressive path into the constitution's history, then it is required a step beyond the methodological horizon of the first, preliminary explications as they've emerged so far. In this different stage of thinking, phenomenology has to commence with "transcendental cognitions of a particular sort" (Fink, 1995, 55), as a result for having "been stranded on the rocks, on the problems that lie at the margins of the regressive analytic, on order from that point to receive the motivating impulse" for a "move beyond the regressive style of intentional-constitutive clarification" (Fink, 1995, 7). Now, the question is: how is it possible? To explain it we need to move over to Fink's architectonic organization of the phenomenological system, in order to clarify how he completes Husserl's thinking with his own proposal of a not regressive (or genetic) but constructive phenomenology. 


\section{THE ARCHITECTONIC OF THE TRANSCENDENTAL SYSTEM: CONSTRUCTIVE PHENOMENOLOGY AND ITS MEONTIC EXTENSION}

The search for this "architectural" solution by Fink - which focuses in particular on the Kantian concept of Architektonik as "the art of systems" - arose from embarrassment facing the task of defining a suitable concept of system for a very particular investigation practice such as Husserl's Arbeitsphilosophie, characterized for maintaining an analytical and intuitive imprint and rejecting any conceptual construction that tends to replace the concrete descriptive findings, as well as every conclusive claim made in the name of a philosophical "spirit of system". Certainly, all Fink's investigations are to be settled on the plane of the totality of the phenomena in order to offer an overall picture in which every phenomenological analysis is placed in accordance with the necessity (nonetheless with Fink's ability and talent as well) to include Husserl's individual analysis in a systematic perspective which could ultimately offer a coherent overview over their mutual implications and connections. Already in the introductory lines of Vergegenwärtigung und Bild (Fink, 1966), Fink exposes his main methodological thesis according to which "no single analysis exists because of itself, and every single one is subordinated to the tension towards the whole of the system, being guided and set in motion by a fundamental question" (Fink, 1966, 2). In such manner, Fink tried to reconcile Husserl's research and experimental process that put in first place the concrete intentional analysis by unraveling the implicit moments of sense of the phenomena up to a systematic and progressive edification of philosophical insights, along with the Heideggerian procedure of an "anticipation of a structural whole", understood as a "constructive project", to which analysis tends to flow back into a function of clarification and exemplification ${ }^{6}$. According to this synoptic point of view, the phenomenological project is conceived by Fink as an intellectual enterprise (a true exercise of thinking) that develops the performance of bracketing the world-validity and the consequent establishing of the transcendental onlooker (Fink, $1995,12)$ in different but interlinked stages of philosophical work, starting with the human self-reflection (inspectio sui) and immediately radicalized into the phenomenological reduction. It is on the basis of this very idea that Fink conceives the architectonic disposition of the different stages of phenomenological work by establishing a fundamental distinction within it and dividing the philosophical system at its onset into a transcendental theory of elements and a transcendental theory of method.

The latter one, focused on the theoretical operations already developed by the philosopher (the phenomenologizing onlooker) - and, surely and above all, the deci-

6 See e.g. Heidegger, (1977, 37, 67, 493). 
sive performance of the reduction - remains in a deep anonymity during the operative development of the theory of elements. The theory of method developed by Fink in the Sixth Cartesian Meditation has essentially to do "with the methods exercised and put in practice in the theory of elements" (Fink, 1995, 25). Consequently, Fink deals there with questions concerning the phenomenological exercise as a fundamental action of reduction, a theoretical experience, an action of ideation, a predication, etc. The important fact is that this methodological reflection can only be unfolded when the previous theory of elements has already taken place, as it has already been performed and developed in a great number of analyses that now have to undergo a deep revision and self-critique.

The transcendental doctrine of elements, whose general object is the becoming of the world (or the "transcendental cosmogony") within the constitutive play between transcendental operations and their worldly results, is divided in two main subjects: regressive and constructive phenomenology, in which the phenomenological onlooker is essentially addressed to constitutive operations of the transcendental subjectivity that reach the world as their final product. The first one is subdivided into an aesthetic and a transcendental analytics, while the latter one is identified with a transcendental dialectic. The transcendental aesthetics acts mainly as a preliminary explanation of the phenomenon of the world by examining and describing the cogitata and their relations with the corresponding cogitations and by pointing out the essential structures of pure consciousness in order to obtain transcendental guidelines for successive constitutive analyses. It corresponds roughly to the concept of a static phenomenology and to Husserl's new employment of the Kantian term e.g. in Formal and Transcendental Logic. The static analysis, thus, aims to expose a system of validities and structural foundations of consciousness' life, i.e. to describe the general structure of intentionality, the various classes of acts and the objectivities appearing on them. The essential structure of the world-experiencing subjectivity is explored in this process, acknowledged as "the condition of possibility of a perfect intuition of the world's construction as the only possible one at all" (Husserl, 1973b, 617). Consequently, static phenomenology is nothing but a descriptive study of the essential structures (eida) of pure consciousness. As a consequence, it acts as a precondition for genetic intentional analysis and, in this case, only when the foundations of existence are known can one trace back their genesis in the course of consciousness' becoming. The proceeding of genetic phenomenology is therefore also called a "regressive questioning". The transcendental analytic achieves the conditions of a regressive phenomenology whenever it returns to the most profound constituent layers of the transcendental-constitutive life and contemplates there the problems belonging to a non-static but genetic description of this 
life as a fluent self-givenness constituted through a permanently becoming, a history of formation and an autopoiesis.

For Fink, nonetheless, the transcendental doctrine of the elements cannot cease here and has to include a new theoretical level as well: the level of a constructive phenomenology that deals with the problems arising from the borders of regressive phenomenology and its genetic developments. Interestingly, Fink does not establish a breach between transcendental aesthetics and logic as Kant does in his Critique of Pure Reason, but does it, rather, between the aesthetics and the analytic on the one hand (settled in continuity relation to the so-called regressive phenomenology) and the dialectic, on the other. This is due to the fact that, for Fink, the truly discriminating factor does not actually operates between intuition and concept, between sensibility (receptivity) and intellect (spontaneity) - but between what is (or can be) phenomenologically given and what is not-given, i.e., between the internal and external horizons of transcendental life, between the findings of a genetic questioning of consciousness and its limits, its dark-zones, which lead to the pointing out of those structures of totality pertaining to the transcendental realm that exceed the merely egological sphere. If the whole phenomenological-analytic work remains "blind" as long as "the totality of all the motivated constructions that go beyond the intuitive givenness of transcendental life" had not been unfolded (Fink, 1995, 8), then the constructive phenomenology is precisely the only way to approach those limit-problems - found at the borders of a regressive intentional analysis and yet impossible to be solved or made explicit in itself due to its interdiction regarding the "presentness" (Gegenwärtigkeit) of transcendental life - without leaving phenomenology itself completely behind but, on the contrary, radicalizing it. The first consequence of this constructive integration of the phenomenological system is that the term "construction", which in Husserl's work received most of the time a negatively connoted meaning, re-emerges in the context of Fink's philosophy designating essentially his concept of a new method that comprises a peculiar transcendental knowledge which, from the point of view of its contents, can be extremely heterogeneous. In this sense, the fundamental differentiation between a constructive and a regressive phenomenology undertaken first of all methodologically by Fink has the duty to consider all "transcendental questions of totality" (Fink, 2008, 124) such as the generative problems of birth and death, the question of history related to the parallelism between the history of the world (of the world understood as the previous reduction) and the transcendental history, as well as the problems concealing the temporality of the last constitutive process and, above all, the question of the enworlding (Verweltlichung), to be minutely discussed in the next section of this paper. 
Bringing phenomenology back into its historical ground, Fink explicitly links the constructive method with Kant's Transcendental Dialectic. Three elements bear the common ground covered by Fink along with the Kantian concept, in spite of the fundamental difference regarding the questioning of both philosophers. First of all: "the relation of the 'given' to the 'non-given'" (Fink, 1995, 64). In both Kant's and Fink's perspectives, the transcendental dialectic deals with "structure of wholeness that are in principle non-given (Fink, 1995, 64): for Kant, it is a question referred to the totality of phenomena that ultimately leads to the cosmological antinomies, whereas for Fink it concerns the totality of transcendental subjectivity and life that reaches beyond the interpretation of what is merely given intuitively in the inner sphere of the presence. In fact, accordingly to Kant, the relations of the "inner world" are not applicable to the (not-given) totality of the world. Secondly, the problem of the subject's unity (or "soul") expressed in the paralogisms of pure reason corresponds, in Fink's disposition, to the phenomenological question about the "coincidence between transcendental subject and its enworlded self-objectivation" (Fink, 1995, 64), and, therefore, also to the problem of beginning and end of the transcendental constituent life and its connection with the already constituted, psychic man. Thirdly, there is an important distinction to be made in the way phenomenological understanding proceeds: constructive phenomenology is no longer "intuitive" but "constructive", just like Kant's Dialectic was no longer "constitutive" but "only of regulative employment" (Fink, 1995, 64). The employment of a Kantian terminology seems to be supported by two important arguments: on the one hand, we are faced with a concept of phenomenology that is not afraid of extending the constitutive investigation to the point of legitimizing "constructions" that involve problems such as "limits" and "totality" (that is, with defining problems of the Kantian Transcendental Dialectic); on the other hand, the point in question here is the undergoing attempt to provide a systematic configuration of phenomenology, to bring together Husserlian micro-analysis in an overall and possibly unitary framework ${ }^{7}$.

The not-given totality of the transcendental life and its structures is now precisely the main question of Fink's own "meontic philosophy". If we take a closer look at the enormous labyrinth of Fink's private notes from the years 1927-1939, what clearly

7 The underlying intention on the basis of Fink's interpretative comparison with the Kantian thought started during the years 1927-1939 and continued intensively in the years of his Freiburg teaching (from 1946 until 1970). His theoretical enterprise aimed not merely to repeat Kant, but to "rethink it", that is - as he affirms in the introduction of his seminary (SS 1968) on Kant's Transcendental Dialectic - to "test a phenomenological-speculative way of thinking in reconsidering the paths of Kantian thought" (Lazzari, 2009, 78). 
emerges there - and exclusively there, that is, nowhere else in his published writings, even if they contain some more or less hidden indications of it - is his systematically and coherently development of the "methodological unity of all phenomenological cognitions that are accessible only by 'construction"' (Fink, 1995, 56) into the core of his so-called meontic, or "meontic philosophy". Accordingly, the term "meontic" was brought up by Fink from the junction of two Ancient Greek particles ( $\mu$ ì and ôv) to designate his own philosophical project in the years of his collaboration with Husserl and - most importantly - to distinguish it decidedly from Husserl's and Heidegger's positions, both of which remained, nonetheless, his main sources of inspiration and polemic targets ${ }^{8}$. Despite of its eminent importance, the term "meontic" is nowhere to be found in the writings published at the time but appears largely in his private notes. The reason for the long-standing silence over the meontic is probably that "the whole idea of meontic is one that opposes the dominant character of Husserlian phenomenology, according to which everything that is thematized must be justified in vivid evidence" (Bruzina, 2006, 196). But how can something essentially un-given be brought to self-givenness and evidence? It cannot. The meontic certainly represents Fink's comprehensive result of that self-critical enterprise, which truly corresponds to the self-referential character of phenomenology in itself, and which has required (and the same for Husserl) a critical examination of the evidence principle and its analytical unfolding into many individual investigations and re-considerations. But Fink's "meontic principle" is not only opposed to the principle of evidence (of phenomenological self-givenness), but, rather, lies beyond the realm of evidence and of the first phenomenological reductive stage in which the present givenness of the ego (and thus of the co-present others) is examined. In fact, the meontic acts no longer "intuitively" but essentially "constructively", most of all due to its relation to a transcendental "non-givenness" that barges into the phenomenological system questioning the wholeness of the transcendental, last-constitutive life and the "coincidence between transcendental subject and its enworlded self-objectivation", the coincidence "between the temporality of bracketed human immanence and that of the transcendental stream of experience" (Fink, 1995, 61).

This mysterious coincidence and "identity in difference, antithesis in self-sameness" (Fink, 1995, 23) between the transcendental (that is, not-in-being) and the worldly sphere of "what is in being" (and therefore between the non- or pre-existent transcendental and the mundane (or human) subjectivity) represents for Fink the very

8 In addition to these main references one should also take into account Nietzsche, Hegel, Kant and the Neoplatonist tradition. 
object of phenomenological philosophy and, in its radicalized form, of a Meontic. An everlasting limitation of phenomenology to the task of describing the consciousness and its intentional structures would be an absurd misunderstanding of its living philosophical intention, for the realm of what is given as describable in terms of consciousness is too limited and far too restricted to cover the entire spectrum of the phenomenological investigation. Furthermore, this necessary limitation is already to be found in the heart of phenomenology itself. For Husserl, the "absolute being" can turn out to be the "subject-being" of the consciousness in which the original constitution (time-constitution) of consciousness itself and of the universe of transcendent objects takes place ${ }^{9}$ if and only if he is able, starting with the Cartesian principle of the apodicticity found in the "ego cogito", to block himself to the access to the me-ontic character of the transcendental consciousness ${ }^{10}$. For Fink, on the contrary, instead of the Absolute itself, the primal ego might be rather its first emanation coming from a primordial life (Ur-Leben) that is prior to the difference between ego and alter-ego and constitutes therefore this plurality by a subsequent self-pluralization ${ }^{11}$. Among the provisional (and surely too short) explications on the phenomenological concept of Absolute, we may find the following excerpt in the last paragraph of the Sixth $\mathrm{Me}$ diation:

What perhaps is shown, then, is that the community of monads itself represents one more constituted stratum in the constitutive becoming of the world. The question is therefore posed whether the transcendental individuation of plural monads is a final and reductively irremovable determination of constituting life. What may then be proven is whether the Absolute itself is articulated in the plural and subjected to an individuation - or whether all articulations are only self-articulations within it, and it itself can only be thought definitively under the Idea of the "One". (Fink, 1995, 145)

Accepting this re-conduction of the inter-subjectivity and monadic plurality to a fully articulated in a constituted plurality an absolute "One" implies a necessarily questioning of the primordial and transcendental emanating life in its unity and totality and even previously to its being, i.e. previously to the moment it came-into-being

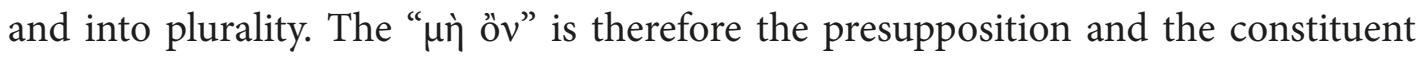
enabling for every constituted being. Not by chance Fink calls it also "origin". As he points out, the Absolute is by no means a being standing beside or outside what is ex-

9 Cf. Husserl, (1976b, 103 ff.).

10 According to Fink, Husserl does not see that the apodicticity of the Cartesian principle is itself an inner-worldly apodicticity, and not a transcendental concept. Cf. Fink (1988, 109-113, 148-157).

11 Cf. Fink $(1976,223)$. On the notion of "phenomenological Absolute" as "primal life" or "absolute spirit" and its development in Fink's early works see Giubilato (2014). 
istent (ontic) and that lies motionless and static in repose. The non-existent (me-ontic) Absolute is only in its constitution, otherwise it is nothing, it is not. Nevertheless, this original "Absolute is only accessible from the ontic, from the finite sphere of constitution". Seen in this way, the Absolute "is in some sense the ontic (what is existent) itself, but questioned so radically that it is the ontic but [an ontic] before its own عival"

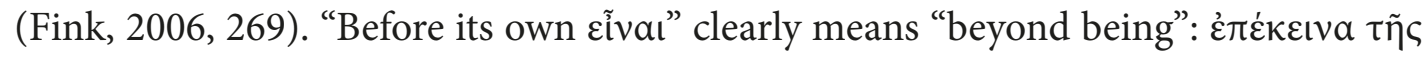
ovoríac. The meontic phenomenology is therefore that very ascension, enabled by the phenomenological reduction, into what lies beyond being: the speculative dimension of the Absolute. In fact, the vertical axis of the "meontic thinking" dialectically links the absolute origin of what is constituted and what is constituting, the "constitutedness of what is in being" (Konstituiertheit des Seienden) (Fink, 2008, 140) and the constitutive process of world's becoming, which is not-in-being but constitutes what is being. As Fink writes in a draft for a foreword to his Sixth Meditation, his aim there was "to formulate a series of problems that remained latent in Husserl's philosophy", and consequently to exercise a reduction "to the deeper life of absolute spirit that lies prior to all individuation" (Fink, 1995, 1). The radical question raised by Fink's meontic can be formulated as follows: how can this process of individuation and emanating from an absolute transcendental life (or spirit) be understood?

\section{THE CONSTRUCTIVE THEORY OF "ENWORLDING" - INDIVIDUATION}

In the very same draft, Finks clearly notes that "Husserl does not carry the distinction between transcendental subject and human over into the dimension of individuation" (Fink, 1995, 1, modified translation). For him, the transcendental ego is indeed a "human" by self-apperceptive constitution. But already in Vergegenwärtigung und Bild, Fink drew attention to the problems concerning the "constitution of the worldly character of the absolute transcendental subject (the constitution of his finitude, of his 'humanity') or, as we say terminologically, to the elaboration of the problem of its enworlding" (Fink, 1966, 9). This means, with other words, the exploration of the "ontological opacity of transcendental life", its coming-into-being, and for that purpose Fink establishes a triple theoretical progression: first of all, he defines the starting point of every phenomenological enterprise, the "natural attitude", as "the essential attitude belonging to all human beings as beings in the whole of the world, [...] the attitude of the enworlded subjectivity: the natural being of man in and to the world in all his modalities" (Fink, 1966, 11). Secondly, and according to what has been just said, the phenomenological reduction is presented as a fundamental movement 
that "springs back from that situation to the absolutely constitutive life, in which it has already constituted a finished world and has itself enworlded in it" (Fink, 1995, 15). Thirdly, he sums up the constitution process as a "finitization" (Verendlichung) of the absolute transcendental life. It involves indeed a questioning of the primordial relation of origin and originated, of the non-existent absolute and its world with existing subjects. Instead of using the term "constitution", Fink uses "ontification": "Ontification: under this title, the meontic phenomenology understands the way of emanation of the origin" (Fink, 2006, 288). From this point of view, his meontic phenomenology of the Absolute is nothing more than an enormous exploration of the ontification process of the Absolute.

But how does the enworlding self-apperception and constitution of intentional experiences take over as psychic acts, constituting them as acts of a psycho-physical human being in the world? In his attempts to clarify and develop this point, Fink distinguishes three levels of enworlding self-apperceptions. First of all, there are all those overlays of knowledge acquired by dealing with others, a knowledge therefore not originated from one's own experience. Secondly, one's own body, namely the inner feeling of corporeality, comes into play. This is given in two ways: once as an acting body in the very immediate inner consciousness of one's own potentialities and as their only and coherent center (Leib) and, secondly, as a "body" in the apperception of the outside world. My body gives itself to a subject in external apperception as "real corporeality" (Körper), as an organ of my possibilities. The third level of self-apperceptions is that of the mental (seelisch) conception of my consciousness: here "the inner experience is understood as the inward sphere of a human in the world" (Fink, 1988, 166-169).

Those three different layers of enworlding self-apperceptions are based on the ultimate ground of self-enworlding of the primal Absolute as human conscious subjectivity in the world. Fink calls it also "Urnoematisierung": the original and primal "noematization" of consciousness (its becoming an "object" of itself) is its "ontification", the process of becoming mundane and human of the transcendental, absolute consciousness "in the constitutively deepest self-apperception" (Fink, 2006, 44). When the three above-mentioned basic forms of self-apperceptions are established in their constituent performance, the consciousness is already an "ontic" consciousness, bearing "ontic" notions: it is a consciousness of a human-being, of a being in the world. According to that, the consciousness' constituting process "Urnoematizierung" through all its different stages resulting in the ontic mode of consciousness as human being, presupposes (and is preceded by) a not-ontic one, a not-being one that is precisely me-ontic. Clearing this point, Fink emphasizes repeatedly that one must understand that the theme of 
phenomenology (or of "phenomenologizing") "as disclosed by the reduction, is not a region or a new field of being, transcendental subjectivity in antithesis to the world", but rather the constitutive process that "goes out from" transcendental absolute life and "and terminates in the end-product, world" (Fink, 1995, 44-45). As the main theme of phenomenological thinking must be regarded the transcendental world constitution in the syntheses and unit formations, habitualities and potentialities of the transcendental life. The term "transcendental life" does not mean just a solipsistic subject, but the all-embracing unity of the monadic inter-subjectivity, "communitized" (Vergemeinschaftung) in the constitution process. The transcendental, self-communitizing absolute life is the starting point (the "whereof") of the constitutive becoming, and the world the "where-to" of its teleological termination, of its "directedness" towards being. Therefore, the self-apperceptions "I" and "world" represent for Fink quasi the first and last hypostases of the constitution process starting from an absolute, me-ontic and emanating life. In it, the constitutive genesis (of subjectivity and world) is not merely an accidens, "not something that goes on merely attributively, [...] as if that subjectivity first already was (as substance, as it were) and then would in addition engage in constitution" (Fink, 1995, 45). Thereby, not the isolated members of the constitutive correlation, but the correlation itself in the absolute, not-yet-in-being transcendental life is the "prior thing": "it is not that subjectivity is here and the world there and between both the constitutive relationship is in play, but that the genesis of constitution is the self-actualization of constituting subjectivity in world-actualization" (Fink, 1995, 45).

One of the most interesting and innovative elements of Fink's theory of the constitutional play interconnecting Absolute and worldly being (with all its plurality of subjects and beings) consists in the fact that he, once again, distinguishes three levels of constitution. First of all, the level of constitution of objects (Noematisierung), which has been extensively studied by Husserl and nevertheless remained his only and principal model for thinking the constitutive process. Secondly, there is the level of the in-stancies (Instände) that constitutes the being-in-the-World of the transcendental subjectivity and, thirdly, the level of the "circum-stancies" (Um-stände) or "around-dimensions" in which the objects are situated and, therefore, the dimension that constitutes the worldly-character of our surroundings (Fink, 2006, 33). The analytic deployment of the constitutive problem of "enworlding" has consequently to follow the stages of constitution of objects, of in-stancies and of circum-stancies. According to Fink, Husserl has operated only in the first level, although his investigations provided the operative basis for a subsequent interpretation of the other two levels.

In his phenomenology of inter-subjectivity, Husserl points out to a particularly important kind of apprehension that contributes significantly to the constitution of 
psychic humanity. This is the "analogizing appresentation", which he determines as an indirect intentionality constitutive for the experience of others (Husserl, 1973a, 138). Due to the physical empathy and because of the "Paarungsassoziation", the apperceptive transmission of senses in which I perceive myself as an ego vis-à-vis with an alter ego becomes possible. This is also the basic principle of the genetic constitution, in contrast to the static constitution centered in perception. Husserl's preoccupation with genetic considerations, then, seeks to locate the constitutive history of consciousness in the sense of a "history of all possible apperceptions" (Husserl, 1966, 339). But in contrast to Husserl, who thinks that those self-apperceptions are derived from coping with others, from the empathy towards them and ultimately from the "secondary" domain of inter-subjectivity, Fink believes that the basic self-apperceptions originate in the immediate original sphere of self-constitution of the subjectivity in the world, and secondly, that they are "not at all of a general type, but have special and purely constitutional differences of their composition" (Fink, 2006, 232). All genetically discoverable self-apperceptions belong to a basic genre, while the other genre would be assigned to the in-stancies. For these, in principle, any "genetic intentional constitutive enlightenment" is possible, and the phenomenological analysis requires therefore new methods for their appropriate understanding and thematization - what, as we have seen, is provided by the constructive phenomenology. While e.g. the "apperception" of one's own body as a natural object are genetically constituted, just as the essential structures of the world are grown associatively, the consolidations of "habits", the in-stancies "are eidetic structures (and so belonging to the essence of consciousness and subjectivity) not affectable by the genetical temporal structure" (Fink, 2006, 233). The problem of their constitution leads ultimately "to the phenomenological marginal problems of the 'ontification of time' and is an explicit introductory theme for a transcendental meontic" (Fink, 2006, 233). From 1927 onwards, the terms Instand, Instände and the adjectival form inständig are frequently found in Fink's private notes, once he has systematically employed it to describe the absolute basic structures of human consciousness (as currently situated in the world) and of human existence as a whole, thought as a result of the self-objectification (or ontification, or enworlding) of the absolute life. Thanks to those in-stancies, among which Fink mentions "history", "birth and death", "being amidst" and "destiny", the subjective life, as the life of a factual man, has its concrete position in the world. The in-stancies are therefore the most original and not-genetic modes of the self-constitution of the Absolute, which in them is finally enworlded, "ontified", and secularized in the world. Fink, probably inspired by an early and profound lecture of Heidegger's Being and Time, considered the "finitude" as the most important of those in-stancies because of the self-constitution 
of the transcendental, absolute life to worldly, human life means primarily a finiteness, a "self-contingentization" into finitude.

The stream of experience is not a stream of intentional experiences that have thereupon a unifying structural moment, a polarization on the ego, but is rather the unity of the Instancies. Only from the ecstatic horizon of the in-stancies (history, birth, death, being amidst, destiny) can happen before of all experience. (Fink, 2006, 239)

But as finite human life is always a consciousness' life in the world, the in-stancies always come along with the "circum-stancies" (Umstände), which are responsible for the constitution of the worldliness of the world. The worldliness of the world is then revealed in the circum-stancies to which the "I also belongs, in which the I is incorporated" (Fink, 2008, 185). The world can be thereby understood more accurately than simply as an ensemble of indefinitely projected potential objects; it is also "the totality of the surround/circum-stance (Umstandsganzheit) for beings", the whole of circumstantiality. In some notes Fink interprets explicitly this concept of world's never fully-given totality on the basis of the ancient concept of кó $\sigma \mu \varsigma$, which for him, at this point, "is nothing other than the circumstantiality that makes up the whole world" (Fink, 2008, 118). This matter has an obvious hermeneutic importance since the "world" is the main concept of the whole Fink's philosophy and since he, mostly in the years after the Second World War, devoted himself to the elaboration of a so called dialectical cosmology.

The phenomenon of circum-stancies plays a central and highly problematical ontological role because, apparently, they are not beings - neither Vorhandenes nor Zuhandenes, as Fink says $(2008,379)$ - , i.e., they are not objects at all. Therefore, there is no thematic consciousness intentionally directed towards objects involved in their experience, but rather a horizontal experience that can grasp the horizons, the circum-stancies in which experience and its objects are given. Accordingly, awareness of circum-stancies is in itself an unthematic-consciousness, or more precisely, circum-stancies are grounded in an unthematic form of consciousness. For the "circum-stancies are constituents of experience, determination of what happens in experience" (Fink, 2008, 379), their localization is a "total different than that of objects" (Fink, 2008, 235). And so, by nature, the two most important "circum-stancies" are time and space, which are not objects but world circumstances. In his drafts and plans, Fink examines particularly spatiality as a prime instance of a "surround", analyzed through the elements of "distance and closeness, silence and sound, night (or darkness) and day (or light), [and] climate (as sun — rain — storm, summer - winter)" (Fink, 2008, 301, 235). Finally, if subjectivity is always a being-in-the-World, 
and if the worldliness of the world is shown in the circumstances, these have also an "existential meaning", or an "in-stancial" significance always involved in it. This means that in-stancies and circum-stancies cannot be investigated separately, but only considering their intertwined constitution.

To conclude we may say that Fink's radicalization of Husserl's phenomenology basically aims at an overcoming of the "classical" horizon model of constitution, which in Husserl's phenomenology represents the transcendental basic structure of the world of experience. Fink is concerned above all with the constitution of the horizons of experience themselves, and thus not with a horizontal but rather vertical constitution of the world as a whole. This problem, as weve seen, refers to the necessary and mutual (inter-)relation of the absolute to the world, i.e to the relation between transcendental and worldly in general. This aspect clearly shows the basic structure of Husserl's transcendental phenomenology, which is played between the "transcendental" and the "mundane". For Fink, however, this dichotomy is no longer interpreted horizontally but vertically or according to the axis of the meontic enworlding process: the self-ontification or self-emanation into finitude of the absolute spirit.

\section{REFERENCES}

Bruzina, R. (1993). The Revision of the Bernau Time-Consciousness Manuscripts: Status Questionis Freiburg (I). Alter, 1, 357-384.

Bruzina, R. (1994). The Revision of the Bernau Time-Consciousness Manuscripts: New Ideas Freiburg, 1930-1933 (II). Alter, 2, 367-395.

Bruzina, R. (2004). Edmund Husserl and Eugen Fink. Beginnings and Ends in Phenomenology,1928 1938. New Haven, London: Yale University Press.

Bruzina, R. (2006). Hinter der ausgeschriebenen Finkschen Meditation: Meontik - Pädagogik. In A. Böhmer (Ed.), Eugen Fink: Sozialphilosophie - Anthropologie - Kosmologie - Pädagogik Methodik (193-219). Würzburg: Königshausen \& Neumann.

Fink, E. (1958). Sein, Wahrheit, Welt. Vor-Fragen zum Problem des Phänomen-Begriffs. Den Haag: Nijhoff.

Fink, E. (1966). Studien zur Phänomenologie 1930-1939. Den Haag: Martinus Nijhoff.

Fink, E. (1976). Nähe und Distanz. Phänomenologische Vorträge und Aufsätze. Freiburg, München: Alber.

Fink, E. (1988). VI. Cartesianische Meditation. Teil 2 Ergänzungsband: Texte aus dem Nachlaß Eugen Fink (1930-1932) mit Anmerkungen und Beilagen aus dem Nachlaß Emund Husserls (1930 1932/33). Dordrecht, Boston, London: Kluwer.

Fink, E. (1995). Sixth Cartesian Meditation. The Idea of a Transcendental Theory of Method. Indianapolis: Indiana University Press.

Fink, E. (2006). Phänomenologische Werkstatt. 3.1: Die Doktorarbeit und erste Assistenzjahre bei Husserl. Freiburg: Alber.

Fink, E. (2008). Phänomenologische Werkstatt. 3.2: Die Bernauer Zeitmanuskripte, Cartesianische Meditationen und System der phänomenologischen Philosophie. Freiburg: Alber. 
Giubilato, G. J. (2014). Sulle spalle dei giganti. Questioni di metodo [Standing on the Shoulders of Giants. Some Methodical Remarks]. In E. Fink, Presentificazione e Immagine [Presentation and Image] (311-325). Milano: Mimesis. (in Italian).

Giubilato, G. J. (2017a). El camino a la libertad. Eugen Fink y el pricipio de la fenomenología [The Path to Freedom. Eugen Fink and the Principle of Phenomenology]. Franciscanum, 176, 23-50. (in Italian).

Giubilato, G. J. (2017b). Freiheit und Reduktion. Grundzüge einer phänomenologischen Meontik bei Eugen Fink (1926-1946). Nordhausen: Bautz.

Heidegger, M. (1977). Sein und Zeit. Frankfurt am Main: Vittorio Klostermann.

Husserl, E. (1959). Erste Philosphie (1923/24). Zweiter Teil: Theorie der phänomenologischen Konstitution. Den Haag: Martinus Nijhoff.

Husserl, E. (1966). Analysen zur passiven Synthesis (Hua XI). Den Haag: Martinus Nijhoff.

Husserl, E. (1969). Formal and Transcendental Logic. Den Haag: Martinus Nijhoff.

Husserl, E. (1973a). Cartesianische Meditationen und Parisier Vorträge (Hua I). Den Haag: Martinus Nijhoff.

Husserl, E. (1973b). Zur Phänomenologie der Intersubjektivität. Dritter Teil: 1929-1935 (Hua XV). Den Haag: Martinus Nijhoff.

Husserl, E. (1976a). Krisis der europäischen Wissenschaften und die transzendentale Phänomenologie. Eine Einleitung in die phänomenologishe Philosophie (Hua VI). Den Haag: Martinus Nijhoff.

Husserl, E. (1976b). Ideen zu einer reinen Phänomenologie und phänomenologischen Philospohie (Hua III). Den Haag: Martinus Nijhoff.

Lazzari, A. (2009). Eugen Fink and the phenomenological interpretations of Kant. Milano: Franco Angeli.

Luft, S. (2002). Phänomenologie der Phänomenologie. Systematik und Methodologie der Phänomenologie in der Auseinandersetzung zwischen Husserl und Fink. Dordrecht, Boston, London: Kluwer.

Van Kerckhoven, G. (2003). Mundanisierung und Individuation. Die VI. Cartesianische Meditation und $i h r$ „Einsatz“. Würzburg: Königshausen \& Neumann. 